\title{
4.15 Підготовка вчителів сврейської діаспори України до впровадження дистанційного навчання в початкову ланку
}

Етнополітика сучасної України переживає сьогодні період становлення, iї ключовим принципом є забезпечення гармонійного співжиття всіх громадян України різних національностей, створення умов для їхнього етнокультурного розвитку. Серед багатьох завдань цього процесу слід виділити, як приоритетне, збереження етнічної ідентичності. Складовою частиною поліетнічного полікультурного простору України є культура єврейського народу. Шлях збереження національної культури в умовах життя у діаспорі - це передусім розвиток національної освіти. Самобутня історія, оригінальна система освіти і виховання молоді стали традиційно найважливішими компонентами культури євреїв України. Єврейська діаспора України має ретельно дбати про розвиток власної освіти, а держава повинна забезпечити умови для такого розвитку.

Серед єврейських національних навчальних закладів, які успішно функціонують у сучасній незалежній Україні, гідне місце займає ВНЗ «Міжнародний гуманітарно-педагогічний інститут «Бейт-Хана», що є закладом, який поєднує академічну підготовку здобувачів вищої освіти 3 практичними завданнями формування професійної компетентності майбутніх педагогів i психологів з урахуванням надбань і традицій національного українського та єврейського виховання, зі спрямуванням на задоволення потреб у забезпеченні вчителями систем формальної і неформальної єврейської освіти та працівниками організацій у структурі єврейських громад. Інститут проводить освітню діяльність за такими спеціальностями та ступенями: 012 Дошкільна освіта, 013 Початкова освіта за освітньо-кваліфікаційним рівнем молодшого спеціаліста; 012 Дошкільна освіта, 013 Початкова освіта, 053 Психологія за освітнім першим освітнім ступенем «бакалавр», спеціальностей 013 Початкова освіта та 053 Психологія за другим освітнім рівнем «магістр».

Запровадження карантину, спричиненого глобальною пандемісю COVID-19, змусило системи освіти багатьох країн світу перейти на дистанційні форми навчання, зокрема і в Україні. Нажаль, система освіти, педагоги, батьки 
та учні переважно не були готові до цього, попри те, що «Положення про дистанційне навчання», в якому були визначені мета, зміст і шляхи його реалізації, було розроблено та затверджено МОН України ще у 2013 році.

Одним 3 найважливіших елементів дистанційної освіти є специфічне кадрове забезпечення, особливістю якого є якісно інші вимоги до викладача: від принципово нового рівня професійних і комп’ютерних знань та умінь до розуміння концептуальних положень й володіння дидактикою дистанційної підготовки. Дистанційне навчання, як результат еволюції системи освіти, активно увійшло до професійної підготовки педагогів, зокрема, вчителів початкових класів. Одним з найважливіших завдань сучасної початкової школи $\epsilon$ створення таких умов навчання учнів, що не тільки збагачують дітей знаннями, але і викликають потребу в пізнанні світу, сприяють збереженню та розвитку культури етнічних громад. Використання дистанційних технологій повинне бути додатковим поштовхом при розв'язанні цих проблем.

Наразі вкрай важливо було посилити роботу 3 формування готовності студентів до організації навчання в нових умовах та використання набутих навичок застосування дистанційних технологій у майбутній професійній діяльності, в тому числі, у закладах із єврейським етнонаціональним компонентом, чому і призвана слугувати дисципліна «Організація дистанційного навчання в початковій школі» для магістрів спеціальності 013 Початкова освіта у ВНЗ «Міжнародний гуманітарно-педагогічний інститут «Бейт-Хана». Вказана дисципліна має на меті підготовку магістрів до застосування в початковій ланці освіти дистанційних технологій навчання як нової форми організації освітнього процесу, що відбувається в основному за опосередкованої взаємодії віддалених один від одного учасників навчального процесу у спеціалізованому середовищі, яке функціонує на базі сучасних психолого-педагогічних та інформаційнокомунікаційних технологій.

Пропонована публікація знайомить 3 досвідом підготовки майбутніх учителів початкових класів до організації дистанційного навчально-виховного процесу з урахуванням єврейського етнонаціонального компоненту. 
Концепція розвитку педагогічної освіти заснована на збалансованому включенні в зміст підготовки вчителів фундаментальних, прикладних i методичних дисциплін, що визначають необхідний професійний рівень сучасного педагога. Ці вимоги було враховано при розробці авторського навчально-методичного комплексу дисципліни «Організація дистанційного навчання в початковій школі», що знайшло своє відображення в змісті матеріалу трьох послідовних блоків: теоретико-методологічного, програмнотехнологічного та предметно-методичного.

Зміст теоретико-методологічного блоку спрямований на формування у студентів розуміння сутності дистанційної освіти, ії нормативно-правової бази та понятійно-термінологічного апарату, дидактичних основ організації дистанційного навчання, вимог до кадрового забезпечення дистанційного освітнього процесу.

При ознайомленні 3 будь-якими фундаментальними теоретичними поняттями неможливо обійтись без розгляду їх витоків, історичних коренів, тож, насамперед слід проаналізувати передумови виникнення дистанційного навчання, історію його розвитку, поділену дослідниками на три етапи, виходячи з відсутності/наявності зворотного зв'язку чи його багатосторонності, який спирається на різні покоління засобів інформації, що обмежені певними проміжками часу. Далі пропонується дослідити нормативно-правове підгрунтя дистанційного навчання в Україні, зміст основних законодавчих та нормативноправових документів з їх прив'язкою до важливих етапів та подій інформатизації освіти. Сутність основних категорій дистанційного навчання багатогранна i різнопланова, відображає різноманітні підходи до його розуміння, що свідчить про стрімкий розвиток цієї галузі освітньої діяльності та намагання знайти оптимальне iii науково-методичне i технологічне наповнення. Тож, слід проаналізувати понятійно-термінологічний апарат дистанційної освіти, представлений як у концепціях, законах, постановах, положеннях, так i в наукових працях вчених-корифеїв цього напряму (В. Биков, М. Жалдак, В. Кремень, В. Кухаренко, В. Осадчий, С. Сисоєва, О. Спірін, А. Хуторськой, 
П. Вольф (P. Wolff), К. Сандерс (C. Saunders), Ч. Скотт (Ch. Scott), Ед Тіттел (E. Tittel) та ін.). Особливо детально розглядається зміст Положення про організацію дистанційного навчання у своєму навчальному закладі [338].

Вирішення складних проблем, що виникають у різних галузях людської діяльності, зокрема, в освіті, може бути ефективним лише за умови використання системного підходу, який вважається одним із провідних методологічних принципів дослідження в кожній галузі знань. Сучасна освіта являє собою складну систему, що об'єднує навчання і виховання, реалізує зміну парадигми навчання з традиційної інформаційної на розвиваючу самостійну пізнавальну. Дистанційна освіта реалізується через систему дистанційного навчання, яка $є$ частиною системи освіти України з нормативно-правовою базою, організаційно оформленою структурою, кадровим, системотехнічним, матеріально-технічним та фінансовим забезпеченням. Розгляд окремих видів забезпечення дистанційної освіти доцільно здійснювати на засадах академічної дидактики - характеристики базових складових дидактичної системи навчання (мети, змісту, методів, засобів, форм) з виділенням суттєвих специфічних рис.

Водночас удосконалення системи освіти залежить не лише від дослідження дидактичних особливостей упровадження сучасних дистанційних технологій в освітній процес та вивчення можливостей різних систем дистанційного навчання, а й від підготовки майбутніх фахівців до роботи в дистанційному інформаційно-освітньому середовищі, оскільки їх зміст та форма суттєво відрізняються від традиційної. У системі дистанційної освіти виділені 4 типи суб'єктів: здобувачі освіти (учні/студенти), тьютори (викладачі, наставники), організатори (для вирішення організаційних питань), адміністратори (для забезпечення стабільного функціонування технічного і спеціального програмного забезпечення, за допомогою якого здійснюється управління дистанційним навчальним процесом).

Для розуміння ролі тьютора в дистанційному навчанні особливо слід виділити соціально значуще i затребуване сьогоденням дисертаційне дослідження Катерини Осадчої «Теоретико-методологічні засади професійної 
підготовки майбутніх учителів до тьюторської діяльності», представлене на здобуття наукового ступеня доктора педагогічних наук у 2020 році [339]. У межах цієї актуальної роботи автором визначено зміст, мету, функції, завдання та методи тьюторської діяльності на основі аналізу вікових особливостей учнів 1-12 класів та провідного виду діяльності для кожного вікового етапу. Підкреслено, що в різних ланках 33СО тьюторська діяльність повинна бути спрямована на розробку й супровід індивідуальної освітньої програми, яка для учнів молодшого шкільного віку в основному спрямована на формування пізнавального інтересу та позитивної мотивації до навчання; для учнів середнього шкільного віку - на підтримку інтересу до навчання з орієнтацією на вибір групи предметів та допрофільну підготовку; для старшокласників - на професійне визначення. На основі такої диференціації виділено різні види тьюторства: залежно від функцій тьютора - тьютор-наставник, тьютор-куратор, тьютор-консультант, тьютор-керівник освітньої траєкторії, тьютор у міждисциплінарній освіті; від сфери здійснення тьюторської діяльності в початковій школі, в основній школі, в старшій школі, у вищій школі, в навчанні дорослих, в інклюзивному навчанні.

У програмно-технологічному блочі розглянуто можливості освітньої Інтернет-комунікації, використання Веб-технологій, послуг хмарних сервісів, спеціальних цифрових інструментів для дистанційного освітнього процесу.

Найперше слід активізувати знання магістрів з основ організації Інтернет, його найпоширеніших послуг (електронної пошти, телеконференцій, файлового сервісу, інтерактивного спілкування), перевірити навички володіння основними прийомами і способами дій, що найбільш властиві мережевим технологіям (навігації гіпертекстовими документами, використанню інформаційнопошукових систем) через виконання завдань, що потребують не тільки технологічних навичок, а й загальнопедагогічних та частковометодичних знань.

При розгляді хмарних технологій визначено їх сутність, як надання кінцевим користувачам віддаленого динамічного доступу до послуг, обчислювальних ресурсів і додатків (включаючи операційні системи та 
інфраструктуру) через Інтернет; рівні (надання програмного забезпечення у вигляді сервісу - SaaS (Software as a service), надання платформи в якості сервісу - PaaS (Platform as a service), надання інфраструктури в якості сервісу - IaaS (Infrastructure as a service)); покоління Веб сервісів та тенденцію розвитку сучасного освітнього середовища в напрямку використання хмаро орієнтованих платформ постачання сервісів і програмного забезпечення - хмаро орієнтованих навчальних середовищ (ХОНС).

На сьогоднішній день в україномовному сегменті мережі Інтернет найбільшою популярністю серед освітян користуються хмарні сервіси корпорації Google, що дозволяють організувати швидке впровадження хмарних технологій у навчально-виховний процес освітніх закладів (Gmail, Google Drive, Google Docs, Google Sheets, Google Slides, Google Forms, Google Meet тощо).

Окремий акцент було зроблено на використанні соціальних мереж, як загальних (Facebook, WhatsApp, Instagram, Twitter, Viber та ін.), так i спеціалізованих (освітніх та наукових). Серед останніх особливо корисними для педагогів є популярні освітні платформи - «Всеосвіта», «На урок», «Освіта», «Освіторія», «Педрада», які надають можливість участі в освітніх проектах, інтернет-конференціях, онлайн-семінарах, перегляду вебінарів, а ще отримання сертифікатів. Також було розглянуто платформи для організації дистанційного навчання, а саме: Zoom - як ресурс комунікаційного програмного забезпечення, який об'єднує відеоконференції, он-лайн зустрічі, чат і мобільну спільну роботу, а також зразки навчальних курсів на платформі Moodle у ВНЗ «Міжнародний гуманітарно-педагогічний інститут «Бейт-Хана».

Заплановано відпрацювання практичних навичок роботи 3 вікісередовищами, зокрема, з україномовною версією веб-енциклопедії Вікіпедія, 3 соціальними геосервісами, а особливо, з сервісами мультимедійних ресурсів засобами, які дозволяють безкоштовно зберігати, класифікувати, обмінюватися цифровими фотографіями, аудіо і відео записами, презентаціями (SlideShare, Flickr, Фотки (fotky.com.ua), Pinterest, Youtube). 
Значну увагу було приділено блогосфері освітян України, причому, як особистим блогам учителів початкової школи, так і суспільним (корпоративним) окремих навчальних закладів. Як приклад можна навести ресурс проекту неформальної освіти «Level Up by Smart J», що реалізується під егідою Федерації єврейських громад СНД, орієнтований саме на єврейські школи з метою підвищення їх ефективності шляхом інтенсифікації позакласного компонента, де в якості пілотних вибрано два напрямки - англійська мова та робототехніка.

У предметно-методичному блоиі здійснено аналіз змістовного, дидактичного та методичного забезпечення з урахуванням можливостей дистанційних форм навчання предметів початкової школи, особливо курсів 3 мов i літератур корінних народів і національних меншин та інших предметів гуманітарного циклу, пов'язаних 3 етнокультурним змістом освіти, зокрема предметів юдаїки. Організація дистанційного навчання не потребує додаткового розроблення і затвердження окремих освітніх програм за освітніми рівнями та навчальних програм із навчальних предметів, здійснюється відповідно до програми закладу освіти та має забезпечувати виконання суб'єктами дистанційного навчання державних стандартів освіти. Вчитель, як і раніше, зобов'язаний виконувати освітню програму для досягнення учнями передбачених результатів навчання, тобто надавати інформацію щодо обсягу та змісту навчального матеріалу, завдань на його закріплення, перевіряти й оцінювати їх та надавати відгуки на виконані завдання. Дистанційний освітній процес повинен реалізовуватися на основі навчальних планів, враховувати кількість годин та специфіку організації навчання різних дисциплін в різних формах: як у режимі онлайн, коли навчальні заходи і взаємодія з педагогом проводиться в режимі реального часу з використанням IКТ, так і в режимі офлайн, який забезпечує учням можливість освоєння навчального матеріалу в будь-який зручний для них час. Учитель, плануючи розклад за скорегованим календарно-тематичним плануванням, має розподілити навантаження, чергуючи навчання у формі відео-інструкцій, онлайн-уроків із завданнями у підручниках і посібниках для самостійного опрацювання. При цьому важливо пам'ятати, 
що за нормами ДСанПІНу час безперервної роботи з комп'ютером в учнів початкових класів не повинен перевищувати 15-20 хв.

У загальному вигляді систему управління змістом освіти можна представити наступним чином:

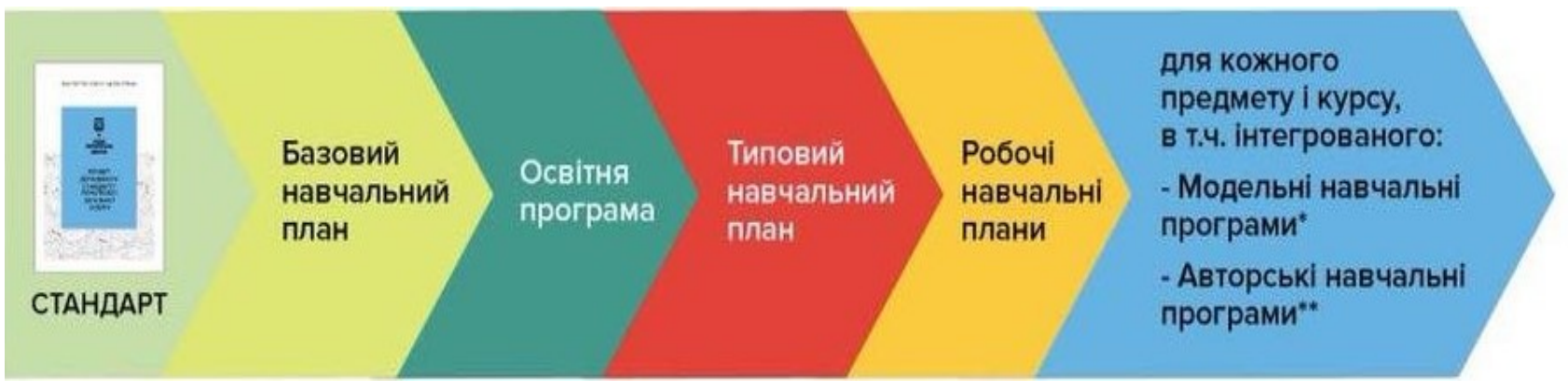

Нова реальність породжує запит на спеціальний науково-методичний супровід навчального процесу, який знайшов своє відображення в комплексах взаємопов'язаних між собою частин. Навчально-методичний комплект (НМК) це сукупність нормативних та навчально-методичних матеріалів на паперовій та/або в електронній формах, необхідних і достатніх для ефективного виконання школярами програми дисципліни, передбаченої навчальним планом. НМК, як сукупність навчальних видань різних видів i форм, містить: програмнометодичні видання (навчальні плани і програми); навчально-методичні видання (методичні вказівки і рекомендації); навчальні видання (підручники і посібники); допоміжні видання (робочі зошити, збірники задач і вправ, практикуми, збірники контролюючих матеріалів, електронні видання тощо). На прикладі змісту складових комплекту інтегрованого курсу «Я досліджую світ» було детально розглянуто забезпечення різних видів діяльності при дистанційній організації навчання в початковій школі зі вказівкою адрес їх електронних варіантів. Також магістрам було пропоновано цілий ряд інтернет-порталів, що 3 настанням карантину в Україні розміщували на своїх сторінках матеріали на допомогу вчителю про роботу шкіл у дистанційному форматі, серед яких сайти НУШ, Академії цифрового розвитку (АЦР), блоги порталів EdEra, НаУрок, Все освіта, а також ресурси обласних Інститутів післядипломної педагогічної освіти.

Окремо було підкреслено особливості підтримки різних видів діяльності здобувачів освіти при дистанційному навчанні - навчально-пізнавальної, 
контрольно-оцінювальної, аналіз дидактичних комплексів

організаційно-виховної.

Відповідно електронних ресурсів здійснювався за основними блоками матеріалів (інформаційно-змістовий, контрольнооцінювальний, розвивальний).

Крім загальної характеристики підходів до організації дистанційного навчання в початковій ланці освіти, практичні аспекти його реалізації розглядалися на прикладі функціонування шкіл із єврейським етнонаціональним компонентом, де студенти нашого закладу проходять різні види практик. Наголос ставився на особливостях навчання івриту в початковій школі. Програма з мови іврит розроблена Наталею Бакуліною з урахуванням вимог Державного стандарту початкової освіти, вікових особливостей розвитку та потреб учнів і забезпечує дітям з єврейських родин можливість повноцінно користуватися рідною мовою як засобом комунікації і пізнання, залучаючись до багатства єврейської культури [340]. Також у співавторстві 3 Іванною Фалесою було розроблено підручники з івриту з додатками (довідник і словник).

Невід’ємною частиною успішної організації процесу навчання івриту є контроль навчальної діяльності відповідно до основних цілей навчання з урахуванням інтересів і можливостей учнів молодших класів. Об'єктами контролю та оцінювання значаться мовні вміння 3 аудіювання, говоріння, читання, письма та сформованість певного кола знань про мову, мовні та правописні вміння, графічні навички письма. Було уточнено засоби діагностики комунікативних компетентностей 3 мови іврит, засоби оцінювання знань і умінь молодших школярів при дистанційному навчанні: спеціальні тестові завдання в Google-формах, вправи з картками в середовищі learningapps.org (https://learningapps.org/10943224, https://learningapps.org/14873045), аудіювання (https://www.youtube.com/watch?app=desktop\&v=u8VS3TRwlgY\&list=PL_0VYN1 GkfMgpS68avctgUFJxo5JxeTBG), творчі та ігрові завдання (https://play.makeit.app/play.html?code=468950), ситуативні діалоги при діалогічному мовленні (https://www.youtube.com/watch?v=UTIFRPD7XGo) тощо. 
Таким чином організоване дистанційне навчання сприяє якісному засвоєнню учнями навчального матеріалу, активному й самостійному виконанню завдань. Однак в умовах карантину не менш актуальною залишається і виховна робота, адже вона має такі важливі функції: профілактичну, ціннісноорієнтаційну, просвітницьку, формування особистісних якостей та гарних манер. Карантин не може стати перепоною для формування правильних цінностей та всебічного розвитку дітей, а також бути на заваді проведення заходів у дусі культури і традицій єврейського народу. Необхідно звернути увагу на такий вид організації роботи на уроках в початковій ланці як ранкові зустрічі, рутини, фізкультхвилинки, які у школах єврейської діаспори проводяться мовою іврит. Також 3 метою ознайомлення 3 національними традиціями, культурою дистанційно проводяться позашкільні заходи на честь національних свят: РошАшана, Йом Кіпур, Симхат Тора, Суккот, Ханука, Пурим, Песах, Лаг ба Омер, Шавуот.

Представлена авторська методика спирається на науково обгрунтовану теоретичну базу та підкріплена апробованими доцільними прикладами, проте потребує подальших наукових розвідок, технологічного удосконалення й методичного розроблення аспектів запровадження дистанційного навчання в систему єврейської освіти України, а запропоновані в даній публікації підходи та дібрані ресурси можуть слугувати практичними рекомендаціями для застосування в освітній практиці. 